\title{
SUSTAINABLE TOURISM DEVELOPMENT OF MOUNTAIN TOURISM DESTINATIONS IN SERBIA
}

Marija Kostić1, Marija Lakićevićn ${ }^{2}$, Snežana Milićević3

*Corresponding author E-mail: marija.kostic@kg.ac.rs

A R T I C L E I N F O

Review Article

Received: 07 May 2018

Accepted: 15 June 2018

doi:10.5937/ekoPolj1802843K

UDC 332.146.2:[338.48-52:797.14](497.11)

Keywords:

sustainable development, sustainable tourism, indicators, mountain destinations, Serbia.

JEL: Q56
A B S T R A C T

Tourism represents the fastest growing branch of economy, which is focused on the realization of economic effects. In the previous period of tourism development, no account was taken of natural resources and the environment. Contemporary trends indicate the existence of a growing demand for preserved natural resources and ecologically clean environment. This trend has caused sustainable tourism development, which will establish a positive relationship between the tourism development and the preservation of the environment. This paper presents the fundamentals of sustainable tourism development. Serbia's mountain areas have a preserved potential of natural resources and the environment, which are the basis for the development of sustainable tourism. The aim of paper is to analyze the previous tourism development of mountain tourist destinations in Serbia, such as Kopaonik and Tara. The indicators of sustainable tourism are tested in this paper, and the results will show whether the previous tourism development in these areas was sustainable or unsustainable.

(C) 2018 EA. All rights reserved.

\section{Introduction}

In the middle of the XX century, i.e. from the year 1950, tourism has experienced an explosive and accelerated growth. Development of mass tourism has led to the economic effects of tourism to become a crucial comparative advantage of tourism development

1 Marija Kostić, Ph.D., Assistant Professor, University of Kragujevac, Faculty of Hotel Management and Tourism in Vrnjačka Banja, Vojvođanska Street 5A, 36210 Vrnjačka Banja, Serbia, Phone: +38162 283124, E-mail: marija.kostic@kg.ac.rs,ORCID ID: https:// orcid.org/0000-0001-8105-8033

2 Marija Lakićević, Ph.D., Assistant Professor, University of Kragujevac, Faculty of Hotel Management and Tourism in Vrnjačka Banja, Vojvođanska Street 5A, 36210 Vrnjačka Banja, Phone: +381 62 609204, E-mail: marija.lakicevic@kg.ac.rs__ORCID ID: https:// orcid.org/0000-0002-1972-9585

3 Snežana Milićević, Associate Professor, University of Kragujevac, Faculty of Hotel Management and Tourism in Vrnjačka Banja, Vojvođanska Street 5A, 36210 Vrnjačka Banja, Phone: +38163621 011, E-mail: snezana.milicevic@kg.ac.rs, ORCID ID: https:// orcid.org/0000-0002-1972-9585 
in one destination. There were recognized numerous economic effects that are created by mass tourist movements, such as increased inflow of foreign funds, increase of employment and income, improvement of pay balance, increase of investments (Bošković, 2008). However, increase of the number of tourists has conditioned a growing and uncontrolled exploitation of natural resources and impairment of the quality of life environment. Natural resources were observed as a means for creating tourism products and meeting tourism needs. Accelerated development of tourism has a negative impact on life environment and natural resources, which is reflected in big amounts of waste, emission of harmful gases and pollution of water, air and land, uncontrolled usage of natural resources, especially non-renewable. On the other hand, the protected areas are becoming a rarer resource in a modern environment, and therefore the interest of tourists in such preserved areas is on the rise (Štetić, Cvijanović, Šimičević, 2014). Many researchers have suggested that the relationship between geography, tourism and protection is dynamic and complex (Sharpley, 2009; Williams, Ponsford, 2009; Nyaupane, Poudel, 2011; Briassoulis, Van der Straaten, 2013; Holden, 2016). Eagles and McCool, 2002 (according to Brankov, 2010) argued that tourism is a fundamental element that determines whether society has awareness and sufficient level of understanding to preserve a certain area.

Tourism should be developed in accordance with the sustainability principles. Sustainability principles require changes in the way of thinking and values, where the changes must include global interdependence, life environment management, social responsibility and economic sustainability (Drumm et al., 2004). Sustainable tourism represents a positive approach that must retain economic advantages of tourism development, but also to reduce negative effects on natural resources and life environment. Sustainable tourism implies such a tourism development that meets the needs of tourists, as carriers of demand, tourist destination as carriers of the offer, with a simultaneous preservation and enlargement of the potentials for using tourist resources in the future, without endangering the possibility of future generations to meet own needs (Hrabovski Tomić, Milićević, 2012).

\section{Impact of tourism on the environment and the need for sustainable development}

Two main fields of tourism impact on life environment are pressure on natural resources and damages of the ecosystem. Uncontrolled development of tourism leads to the degradation of life environment, but also degradation of life environment in return represents a serious threat to tourist activities (Neto, 2003). There are numerous negative impacts of tourism on the environment that can be classified in the following manner (Maksin et al., 2009, p.19):

- economic - destruction of the traditional form of business (especially agriculture and fishing), a significant share of non-qualified and poorly paid jobs for local workforce, high import dependence and reduction of foreign inflows, etc;

socio-cultural - loss of cultural identity, disappearance of traditional value systems, crime, marginalization and stratification of population, etc; 
- $\quad$ ecological - increased scope and intensity of using natural resources, creation of big amounts of waste, increased noise and emission of harmful gases, occupation of agricultural land and forests for tourist purposes and contents, etc.

In addition to direct negative impacts of tourism on the environment, there are both indirect and induced impacts of tourism. Indirect impact refers to newly-built accommodation capacities or other capacities of tourist industry in a specific tourist region that provide increase of employment of both local population and population from other regions, which is a positive indirect effect of tourism, but simultaneously increased capacities result in the increase of the number of tourists who perform a significant pressure on the life environment and usage of natural resources. Induced impact of tourism refers to the development of other industrial branches (e.g.agriculture) in the environment in order to meet tourist needs. The increase of the number of tourists results in the increased needs for food, i.e. agricultural products, which further affects the increase of the scope of agricultural production and extension of agricultural surfaces, increase of the usage of mineral fertilizers, increased consumption of water resources and pollution (Weaver, 2006).

In the last couple of decades, when creating tourist offer, we did not pay much attention to the protection of natural resources and life environment, since the advantage was given to the achievement of economic profit. However, the appearance of ecological issues, due to uncontrolled and accelerated tourism development have started to point to the conclusion on reduction of desirability among the tourists. Over the time, we have come to the idea on application of sustainable development concept which should provide the preservation of natural resources and life environment. The application of sustainable tourism concept should contribute to the minimization of negative impacts of tourism to the environment and maximization of positive effects of tourism, which will provide a long-term development of tourism.

\section{Research methodology}

Main goal of the research is the observation of previous tourism development on the mountains of Serbia, as well as observation of effects of applying the indicators of sustainable tourism on the example of Kopaonik and Tara mountains (and national parks, also) which should show whether previous development of tourism was sustainable or not. National parks are the most complex category of protected resources. Due to their protected status, these areas should conform to the sustainable forms of tourism development (Brankov, 2010; Brankov, 2015; Brankov et al., 2015). Having in mind that mountains of Serbia own a diverse and mainly unimpaired potential of natural resources, application of the elements of sustainable tourism concept must become crucial when projecting future tourist development of Serbia. Starting from a defined subject and goals of study, there were the following research hypotheses set:

$\mathbf{H}_{\mathbf{1}}$ : Development of sustainable tourism is a result of the increase of tourist demand for a quality life environment and unimpaired natural resources. 
$\mathbf{H}_{2}$ : Application of sustainable tourism concept has a positive effect on tourism development in the long run.

$\mathbf{H}_{3}$ : Develeopment of tourism on Kopaonik is based on unsustainable bases that are not acceptable in the long run.

$\mathbf{H}_{4}$ : Tara owns a potential for the sustainable tourism development in the following period. In accordance with the set subject and goals of the research, as well as main research hypotheses, in this paper we have applied quantitative and qualitative methodology.

\section{Comparative indicators of sustainable development of $\mathbf{E U}$}

Monitoring of the effects of tourism development, i.e. verification of the progress in the aspect of sustainable tourism development cannot be imagined without appropriate indicators (Miller, 2001). Indicators provide monitoring and measurement of changes in development of sustainable tourism over the time with the aim to more easily observe the trends of sustainable tourism development and avoid unpredicted harmful effects. According to the World Tourism Organization, indicators are measures or existence or seriousness of current issues, signals of the upcoming situations or issues, measures of risks and potential needs for acting and means for identification and measurement of the results of actions occurred. They are the set of information that were formally selected to be regularly used in measurement of changes that are significant for tourism development. Good indicators provide some of the following benefits (WTO, 2004):

- Better decision making - reduces risk or costs,

- Identification of urgent issues - provides prevention,

- Identification of impacts - provides corrective actions when it is necessary,

- Measurement of the effect of the plans implemented and managerial activities provides a progress in sustainable development of tourism,

- Reduces the risk of planning mistakes - identifying constraints and possibilities,

- Greater responsibility - provides authentic information for the public and interest groups in tourism encouraging the responsibility for a wise decision making,

- Continuous monitoring can lead to continuous improvements.

Comparative indicators integrate economic, ecological, social and cultural factors, as well as satisfaction of tourists. Accordingly, the indicators have been classified into five groups which are shown in Table 1, (Jovičić, Ilić, 2010):

- Economic indicators - show economic effects of tourism business in tourist place and region;

- Satisfaction of tourists - level of satisfaction of tourists with the quality of tourist capacities and services provided, as well as their opinion on attractiveness of motives, state of life environment and socio-cultural characteristics of receptive region; 
- Social indicators - reflect social integrity of local community, from the aspect of subjective welfare of domicile population in tourist destination;

- Cultural indicators - express the level of preservation of cultural identity of local community, under the effect of the impact of tourists who come from the environments with a different cultural characteristics;

- Indicators of the state of life environment - they should provide the image of the state of life environment and impacts that tourism has on particular media (water resources, air, biodiversity, land).

Table 1. Comparative indicators of sustainable tourism

\begin{tabular}{|c|c|c|}
\hline Type of indicators & Indicator & Interpretation \\
\hline \multirow{3}{*}{ Economic } & $\begin{array}{l}\text { Seasonal character of the circulation: \% } \\
\text { visits in full season ( } 3 \text { months) }\end{array}$ & $\begin{array}{l}<40 \% \text { green zone } \\
40-50 \% \text { yellow zone } \\
>50 \% \text { red zone } \\
\end{array}$ \\
\hline & $\begin{array}{l}\text { Ratio of nights and accommodation } \\
\text { capacities }\end{array}$ & $\begin{array}{l}>150 \% \text { green zone } \\
120-150 \% \text { yellow zone } \\
<120 \% \text { red zone } \\
\end{array}$ \\
\hline & Coefficient of local tourist increase & Not specified \\
\hline Satisfaction of tourists & $\begin{array}{l}\text { Repeated visits: \% repeated vists in the } \\
\text { period of } 5 \text { years }\end{array}$ & $\begin{array}{l}>50 \% \text { green zone } \\
30-50 \% \text { yellow zone } \\
<30 \% \text { red zone }\end{array}$ \\
\hline \multirow{2}{*}{ Cultural } & $\begin{array}{l}\text { Relationship of accommodation capacities } \\
\text { and number of local population }\end{array}$ & $\begin{array}{l}<1,1: 1 \text { green zone } \\
1,1-1,5: 1 \text { yellow zone } \\
>1,6: 1 \text { red zone } \\
\end{array}$ \\
\hline & $\begin{array}{l}\text { Tourism intensity: number of nights }(000) \\
\text { according to population }(00)\end{array}$ & $\begin{array}{l}<1,1: 1 \text { green zone } \\
1,1-1,5: 1 \text { yellow zone } \\
>1,6: 1 \text { red zone } \\
\end{array}$ \\
\hline \multirow{2}{*}{ Social } & Share of tourism in local net social product & $\begin{array}{l}\text { We should compare with } \\
\text { a share of tourism in local } \\
\text { employment }\end{array}$ \\
\hline & $\begin{array}{l}\% \text { of tourists who do not come through the } \\
\text { tour operators }\end{array}$ & $\begin{array}{l}>70 \% \text { green zone } \\
50-70 \% \text { yellow zone }<50 \% \\
\text { red zone }\end{array}$ \\
\hline \multirow{3}{*}{$\begin{array}{l}\text { Indicators of the state of } \\
\text { life environment }\end{array}$} & $\begin{array}{l}\text { Land: \% land in which construction was } \\
\text { built but it is not implemented }\end{array}$ & $\begin{array}{l}<10 \% \text { green zone } \\
10-20 \% \text { yellow zone } \\
>20 \% \text { red zone }\end{array}$ \\
\hline & $\begin{array}{l}\text { Usage and occupation of land: \% change in } \\
\text { construction of region within } 5 \text { years }\end{array}$ & Still not specified \\
\hline & $\begin{array}{l}\text { Transport: \% of arrival of tourists who do } \\
\text { not use private cars }\end{array}$ & $\begin{array}{l}>20 \% \text { green zone } \\
10-20 \% \text { yellow zone } \\
<10 \% \text { red zone }\end{array}$ \\
\hline
\end{tabular}

Source: Stojanovic, V. (2011), Turizam i održivi razvoj, Novi Sad: Prirodno-matematički fakultet

The application of economic, cultural, social indicators, as well as indicators of the state of life environment and satisfaction of tourists, is based on coding system, by which we determine border values for each indicator. Border value is the value or range of values, 
which identifies critical change of a specific indicator. It often labels demarcation line between sustainable and unsustainable type of tourist development (Jovičić, Ilić, 2010, p.270). Based on border values, by indicators we evaluate the state of tourism development as: critical, bearable and sustainable, and thus they are called warning indicators. By the mentioned coding system there are three zones introduced, and each of them reflects current state of tourism development in a particular destination. Those zones are (Stojanović, 2010, p. 225).

- Red zone - labels that situation is critical and that it is required to take appropriate measures at once, in order to modify further development of tourism, put it under firmer control or even stopped;

- Yellow zone - points out that situation is bearable, but that progressive growth of tourism in the following period can cause serious problems so it is recommendable to undertake certain preventive measures;

- Green zone - the existing state of tourism development is evaluated as sustainable, which is the result of a quality management and purposeful measures and activities undertaken in the previous period:

In the paper, there is given the presentation of the movement of the indicators of sustainable tourism for the two selected mountains, Kopaonik and Tara.

\section{Application of indicators of sustainable tourism on the example of Kopaonik}

Application of comparative indicators of sustanable tourism of EU on the example of Kopaonik, should show whether and to what extent in sustainable development of tourism achieved. A more detailed interpretation of particular indicators of sustainable tourism development of Kopaonik which were analyzed based on the achieved tourism indicators in the year 2016 are shown in Table 2.

Table 2. Indicators of sustainable tourism for Kopaonik

\begin{tabular}{|l|l|l|l|}
\hline Type of indicators & Indicator & \multicolumn{2}{|l|}{ Interpretation } \\
\hline \multirow{5}{*}{ Economic } & $\begin{array}{l}\text { Seasonal character of the circulation: \% } \\
\text { visits in season (3 months) }\end{array}$ & $51,02 \%$ & $\begin{array}{l}\text { Red zone } \\
\text { (unsustainable) }\end{array}$ \\
\cline { 2 - 4 } & $\begin{array}{l}\text { Ratio of nights and accommodation } \\
\text { capacities }\end{array}$ & 91,74 & $\begin{array}{l}\text { Red zone } \\
\text { (unsustainable) }\end{array}$ \\
\cline { 2 - 4 } Satisfaction of tourists & $\begin{array}{l}\text { Coefficient of local tourist increase } \\
\text { pepeated visits: \% repeated visits in the } \\
\text { period of 5 years }\end{array}$ & Small & $\begin{array}{l}\text { Green zone } \\
\text { (sustainable) }\end{array}$ \\
\hline Cultural & $\begin{array}{l}\text { Ratio of accommodation capacities and } \\
\text { the number of local population }\end{array}$ & $3,38: 1$ & $\begin{array}{l}\text { Red zone } \\
\text { (unsustainable) }\end{array}$ \\
\cline { 2 - 4 } & $\begin{array}{l}\text { Tourism intensity: number of nights } \\
\text { (000) according to the number of } \\
\text { people(00) }\end{array}$ & $30,94: 1$ & $\begin{array}{l}\text { Red zone } \\
\text { (unsustainable) }\end{array}$ \\
\hline
\end{tabular}




\begin{tabular}{|c|c|c|c|}
\hline Type of indicators & Indicator & Interpretatio & \\
\hline \multirow{2}{*}{ Social } & $\begin{array}{l}\text { Share of tourism in local net social } \\
\text { product }\end{array}$ & \begin{tabular}{|l|}
$\begin{array}{l}\text { Significant } \\
\text { and growing }\end{array}$ \\
\end{tabular} & \\
\hline & $\begin{array}{l}\text { \% tourists who do not come through the } \\
\text { tour operators }\end{array}$ & Over & \begin{tabular}{|l|}
$\begin{array}{l}\text { Green zone } \\
\text { (sustainable) }\end{array}$ \\
\end{tabular} \\
\hline \multirow{3}{*}{$\begin{array}{l}\text { Life environment state } \\
\text { indicators }\end{array}$} & $\begin{array}{l}\text { Land: \% of land where construction is } \\
\text { allowed but not realized }\end{array}$ & - & - \\
\hline & $\begin{array}{l}\text { Usage and occupation of land: \% of } \\
\text { changes in construction of region within } \\
5 \text { years }\end{array}$ & $\begin{array}{l}\text { Too much } \\
\text { constructed }\end{array}$ & \\
\hline & $\begin{array}{l}\text { transport: \% of arrival of tourists who } \\
\text { do not use private cars }\end{array}$ & $10 \%$ & \begin{tabular}{|l} 
Red zone \\
(unsustainable)
\end{tabular} \\
\hline
\end{tabular}

Source: Author's research

Seasonal character of tourist circulation - According to the data of the Republic Bureau of Statistics of the Republic of Serbia, on Kopaonik in 2016 there were 495.753 nights recorded, i.e. 117.942 tourist visits (RZZS, 2016). Of that number, in the three most visited winter months (January, February and March) there was recorded 252.919 nights or $51,02 \%$ of the total number of tourist nights realized in the year 2016 . When we observe border values for seasonal concentration of tourist circulation within three most visited months, value of the indicator obtained of $51,02 \%$ points to the red zone, i.e. unsustainable situation for natural resources and life environment of this tourist organization.

Ratio of nights and accommodation capacities is 91,74 nights per bed and also points to the red zone, i.e. low level of using accommodation capacities. Kopaonik has untimately unsustainable value of this indicator, which points to the conclusion that there are enough accommodation capacities, so it is required to invest in development of new forms of tourism which will contribute to greater usage of accommodation capacities in the following period.

Coefficient of local tourist increase - development of tourism on Kopaonik should encourage development of a big number of industrial branches (agriculture, trade, transport, etc.). Unfortunately, tourism on this mountain has not contributed significantly to the development of other industrial branches, whose products and services make integral components of the total tourist offer. According to that, we can say that coefficient of the local tourist increase is small because Kopaonik has not used tourism development for the increase of local economy.

Repeated visits of tourists represent an indicator of tourists' satisfaction with a particular destination. For determination of this indicator there are no adequate data available, since the statistics of repeated vists is not led. Of the total number of reviewed people, $80 \%$ of respondents have stated that they stayed on Kopaonik once or several times and $75 \%$ said that they would visit this destination once more. According to the EU criterion, this percentage belongs to the green zne, which means that Kopaonik is attractive, that it is well-positioned in tourism market, that tourist products that it offers are acceptable to tourists and that it offers high-quality satisfaction. 
Ratio of accommodation capacities and number of local population on Kopaonik is unsustainable. Namely, number of accommodation capacities in 2016 was 5.404, and number of people living on the mountain and offering tourist services is 1.600 (RZZS, 2016). By putting these two factors together we obtain the proportion of 3,38:1. According to EU criterion, value of this indicator belongs to the red zone, which means that tourism on Kopaonik is unsustainable because excessive number of accommodation capacities has a negative impact on cultural identity of local community, we get the impression that tourist place is overloaded, which has a negative effect on the quality of tourist experience.

Intensity of tourism shows the ratio of the number of nights and population. Number of nights on Kopaonik in 2016 was 495.753 (RZZS, 2016), while the number of local population offering services to tourists was 1.600. Proportion is 30,94:1, which means that cultural identity of local community is under the excessive impact of tourism because the proportion mentioned belongs to the red zone. Therefore, on Kopaonik, circulation of tourists reaches great proportions, which jeopardizes cultural identity of local community and reduces the quality of tourist experience.

Share of tourism in local net product shows the contribution of tourism to the creation of local domestic product. Precise data for determination of this indicator do not exist, but we can provide a qualitative evaluation. Since tourism is a dominant industrial branch on Kopaonik, tourism development has a positive effect on development of local community, so we can conclude that share of tourism in local domestic product is significanta dn growing, which is positive from the aspect of sustainable tourism development.

Percentage of tourists who do not come through tour operators cannot be determined based on quantitative data because there are no precise data that point to the manner of tourists arrival. We can say that more than $70 \%$ of tourists do not come through tour operators, which is a green zone according to the EU criterion, i.e. value of this indicator is considered an indicator of sustainable tourism.

Usage and occupation of land, as an indicator of the life environment state, shows the changes in the purpose of using the land, through the increase of construction of tourist capacities. In case of this indicator, there are not defined border values, but the extention of tourist capacities that occupation of new land requires has a negative effect on life environment. By analyzing the data of the Republic Bureau of Statistics, number of accommodation capacities in 2010 was 4.325 beds (RZZS, 2011), while that number has grown up to 5.404 in 2016. (RZZS, 2016), which means that the number of beds on Kopaonik was increased by $20 \%$. Kopaonik has through tourism development experiences an exceptional level of urbanization, since the number of accommodation capacities was increased more than it should. Scope of building the capacities for accommodation of tourists is not satisfactory, particularly from the aspect of location of the construction which is labeled as national park. Construction of infrastructure has greatly changed primary appearance of this protected area and degraded its resource 
potential. By analyzing the level of tourist capacities construction, we can say that Kopaonik is too much contructed.

Percentage of tourists who do not come by private cars is related to the indicator which marks the percentage of tourists who do not come through tour operators. During main tourist season, on Kopaonik there is an issue of great traffic jams and parking, which points out that a great number of tourists come by their private cars. Having in mind that there are no precise data for establishment of this indicator, we can say that about $10 \%$ of tourists do not come by their own transport means, which according to EU criterion is included in the red zone, i.e. zone of unsustainability of tourism from the aspect of life environment.

Based on the analyzed indicators of sustainable tourism on Kopaonik we can conclude that previous concept of tourism development was not in accordance with sustainable development principles and that it is not acceptable in the long-run. Out of 10 indicators analyzed, even five of them belong to the red zone, while only two are in the green zone, which clearly points out that tourism development on Kopaonik is not developed in accordance with sustainable development principles. In order to improve total effects of tourism it is required to change or complement the existing forms of tourism with some new forms that will be in accordance with sustainable tourism development.

\section{Application of sustainable tourism indicator on the example of Tara}

Application of comparative indicators of EU sustainable tourism on the example of Tara is given by the presentation in Table 3.

Table 3. Indic0ators of sustainable tourism on the example of Tara

\begin{tabular}{|c|c|c|c|}
\hline Type of indicators & Indicator & Interpretation & \\
\hline \multirow{3}{*}{ Economic } & $\begin{array}{l}\text { Seasonal character of circulation: } \\
\% \text { of visits in season ( } 3 \text { months) }\end{array}$ & $38,62 \%$ & $\begin{array}{l}\text { Green zone } \\
\text { (sustainable) }\end{array}$ \\
\hline & \begin{tabular}{|l|} 
Ratio of nights and \\
accommodation capacities
\end{tabular} & 347,03 & \begin{tabular}{|l|}
$\begin{array}{l}\text { Green zone } \\
\text { (sustainable) }\end{array}$ \\
\end{tabular} \\
\hline & $\begin{array}{l}\text { Coefficient of local tourist } \\
\text { increase }\end{array}$ & medium & \\
\hline Satisfaction of tourists & $\begin{array}{l}\text { Repeated visits: \% repeated visits } \\
\text { in the period of } 5 \text { years }\end{array}$ & $50 \%$ & \begin{tabular}{|l} 
Green zone \\
(sustainable)
\end{tabular} \\
\hline \multirow{2}{*}{ Cultural } & $\begin{array}{l}\text { Ratio of accommodation } \\
\text { capacities and number of local } \\
\text { population }\end{array}$ & $0,25: 1$ & $\begin{array}{l}\text { Green zone } \\
\text { (sustainable) }\end{array}$ \\
\hline & $\begin{array}{l}\text { Tourism intensity: number of } \\
\text { nights }(000) \text { according to the } \\
\text { number of people }(00)\end{array}$ & $8,68: 1$ & $\begin{array}{l}\text { Red zone } \\
\text { (unsustainable) }\end{array}$ \\
\hline \multirow{2}{*}{ Social } & $\begin{array}{l}\text { Share of tourism in local net } \\
\text { domestic product }\end{array}$ & $\begin{array}{l}\begin{array}{l}\text { Significant and } \\
\text { growing }\end{array} \\
\end{array}$ & \\
\hline & $\begin{array}{l}\% \text { of tourists who do not come } \\
\text { through tour operators }\end{array}$ & $60 \%$ & $\begin{array}{l}\text { Yellow zone } \\
\text { (partially sustainable) }\end{array}$ \\
\hline
\end{tabular}




\begin{tabular}{|c|c|c|c|}
\hline Type of indicators & Indicator & \multicolumn{2}{|c|}{ Interpretation } \\
\hline \multirow{3}{*}{$\begin{array}{l}\text { Life environment state } \\
\text { indicators }\end{array}$} & $\begin{array}{l}\text { Land: \% of land where } \\
\text { construction is allowed but not } \\
\text { realized }\end{array}$ & - & - \\
\hline & $\begin{array}{l}\text { Usage and occupation of land: \% } \\
\text { of changes in construction of the } \\
\text { region within } 5 \text { years }\end{array}$ & $\begin{array}{l}\text { Sufficiently } \\
\text { built }\end{array}$ & \\
\hline & $\begin{array}{l}\text { Transport: \% of arrivals of } \\
\text { tourists who do not use private } \\
\text { cars }\end{array}$ & $20 \%$ & $\begin{array}{l}\text { Yellow zone } \\
\text { (partially sustainable) }\end{array}$ \\
\hline
\end{tabular}

Source: Author's research

Detailed interpretation of particular indicators of sustainable tourist development of Tara was analyzed based on the achieved tourist indicators in 2016.

Seasonal character of tourist circulation - On Tara in 2016 there was realized 243.613 of nights, i.e. 63.651 tourist visits (RZZS, 2016). Of the total number of tourists, during the three most visited months (April, May and June) there was recorded 24.580 tourists or $38,62 \%$ of the total number of tourists in 2016 . When we observe border values for seasonal concentration of tourist circulation within the three most visited months, value of the indicator obtained of $38,62 \%$ points to the green zone, i.e. sustainable situation for natural resources and life environment of this destination.

Tara realizes sustainable values of the indicator analyzed, since it has a relatively harmonized visit of tourists by months. From the standpoint of sustainable development of tourism, it goes in favour of tourist workers and the destination itself. The three most visited months are April, May and June, since recreational classes for primary schools' students is organized here. Even concentration of tourists does not reduce the quality of tourist experience and evenly performs pressure on natural resources and life environment. From the aspect of sustainable development of tourism, even concentration of tourists is desirable and acceptable, because it shows that developed forms of tourism do not depend on climate factors.

Ratio of nights and accommodation capacities was 347,03 nights per bed, which is a result that points to the green zone, i.e. sustainable value of this indicator. Therefore, on Tara there is a high level of accommodation capacities exploitation.

Coefficient of local tourist increase - tourism development on Tara should encourage the development of a great number of industrial branches. Having in mind that there are no precise data that would provide the determination of this indicator, there is only a qualitative evaluation given. Observing the development of other industrial branches we can conclude that tourism has had a significant contribution to their development because products and services of local area are included in tourist offer, but there still isn't achieved a satisfying level so we can say that coefficient of local tourist increase is medium.

Repeated visits of tourists show that of the total number of interviewed people, $50 \%$ of respondents have said that they have stayed on Tara mountain once or several times, 
and $45 \%$ that they would visit this destination once more. According to the EU criterion, this percentage is on the border between green and yellow zone, which means that Tara is well-positioned on tourist market, that tourist products that it offers are acceptable to tourists and that it offers the satisfaction of high quality.

Ratio of accommodation capacities and the number of local population on Tara is sustainable and it is $0,25: 1$. Value of this indicator belongs to the green zone, which means that tourism on Tara is sustainable because a number of accommodation capacities is significantly lower in relation to the number of local population. Sustainable value of this indicator points to insignificant impact of tourism to the cultural identity of local community.

Tourism intensity with the value of $8,68: 1$ points that cultural identity of local community was under the impact of tourists because the mentioned proportion belongs to the red zone. Therefore, Tara is a destination where circulation of tourists reached the proportions that jeopardize cultural identity of local community and reduce the quality of tourist experience.

Share of tourism in local net product points to the contribution of tourism to the creation of local domestic product. Precise data for determination of this indicator do not exist, but we can give a qualitative evaluation. Since tourism is dominant industrial branch on Tara, development of tourism has a positive effect on development of local community so we can conclude that share of tourism in local net product is significant and growing, which is positive from the aspect of sustainable development of tourism.

Percentage of tourists who do not come through tour operators cannot be determined based on quantitative data, because there are no precise data that point to the manner of tourists arrival. We can say that about $60 \%$ of tourists do not come through tour operators, which according to the EU criterion is a yellow zone, i.e. value of this indicator is considered the indicator of sustainable tourism.

Usage and occupation of land is determined according to the data of the Republic Bureau of Statistics of the Republic of Serbia (Statistical Yearbook, 2016), by comparing the number of accommodation capacities in 2011 (1117 beds) and in 2016. (702 beds). Scope of construction of capacities for accommodation of tourists is satisfactory, having in mind that Tara is pronounced as national park. Construction of tourist infrastructure has not changed primary appearance of this protected area and degraded its resource potential, which is good from the aspect of sustainable development of tourism.

Percentage of tourists who do not come by private cars points out that the situation on Tara can be labeled as partially sustainable from the aspect of environmental protection and preservation of natural resources, since there are tourists who do not come by their own cars. In favour of that, there is a relatively good network of bus lines in the mountain region of Tara. Having in mind that there are no precise data for establishment of this indicator, we can say that about $20 \%$ of tourists do not come by their own cars, which according to the criterion of EU is in the yellow zone, i.e. zone of partial sustainability of tourism from the aspect of life environment. 
Based on the analysis implemented we can conclude that out of 10 analyzed indicators of sustainable tourism, four indicators belong to the green zone, two to yellow, while only one indicator belongs to the red zone, so we can conclude that tourism development on Tara is developed in accordance with sustainable development. This points to the fact that previous development of tourism was in accordance with sustainable development principles.

\section{Conclusion}

Mountain destinations of Serbia and resources that are found in them are the basis of future economic development of the country. Serbia disposes with relatively preserved natural resources, so development of tourism should be in accordance with sustainable development. However, development of mountain tourism in previous period was oriented on mass tourism development. It is best observed on the examples of Kopaonik and Tara. In addition, excessive visits of tourists resulted in mass construction of tourist capacities, as well as big concentration of traffic in these destinations, which has impaired the quality of natural resources and life environment. Previous development of mountain tourism of Serbia was mainly oriented on winter tourism, which is economically costeffective, but contributes to degradation of sensitive mountain nature.

Kopaonik and Tara represent destinations with long-term tradition of tourism development. After the analysis of previous tourism development on Kopaonik, we have come to the conclusion that seasonal character is expressed during winter months, which is not acceptable solution from the aspect of sustainable development of tourism. Kopaonik has a low level of accommodation capacities exploitation, and thus the investments in development of new forms of tourism that will contribute to greater exploitation is required. Having in mind that Kopaonik has a status of national park, a great level of constructed tourism infrastructure has largely changed the primary appearance of this protected area and degraded its resource potential, which is not good. This destination also has a problem with big concentration of the traffic, since most tourists come by private cars, which is also unsustainable. On the other hand, seasonal character of tourist circulation on Tara is sustainable according to the criteria prescribed. Relatively even allocated tourist visits during the whole year are an acceptable solution from the aspect of sustainable development of tourism because pressure to the environment is even and the quality of tourist experience is not reduced. In addition, Tara is specific for sufficient construction of tourist capacities and there is a high level of exploitation of them, which is also positive from the aspect of sustainable development of tourism. Most tourists use own cars when they visit this destination, but there is also a significant share of organized arrivals, which is partially sustainable according to the criteria defined.

From all above-mentioned, we can conclude that Kopaonik, as economically most developed tourist destination, due to excessive and uncontrolled construction of tourist infrastructure, impaired natural appearance of space, impaired life environment and natural resources has reduced possibilities for sustainable development of tourism in the following period. On the other hand, Tara, as economically less developed destination, 
is characterized by intact and unimpaired nature and preserved natural resources, so it possesses the potential for development of sustainable tourism in the following period.

In order to achieve sustainable development of tourism it is required to limit, reduce or balance the concentration of tourists, which can be achieved by diversification of tourist products and development of annual tourism. In addition, we should constrain the usage of private cars and reorient tourists for the usage of public transport or ecologically sustainable forms of transport. Mountain areas of Serbia dispose with rich natural resources, which can be used for development of sustainable tourism during the whole year and existing tourist capacities and image built be development of winter mass tourism can serve as a basis for development of sustainable forms of tourism in the following period. What characterizes mountain areas of Serbia is lagging behind in the aspect of sustainable development of tourism in relation to the majority of European countries, since there is no clearly defined strategy of development and protection of mountain areas, not to mention an efficient system of sustainable development management. (Krunić, Milijić, Đurđević, 2010), because sustainable development of tourism is a goal that cannot be entirely achieved, but which should be strived for in the long run (Popesku, 2016). In order to provide sustainable development of tourism, the support and incentives of the country are required as well as providing advantage for the ecologically acceptable tourist offer. The greatest potential for development of sustainable tourism have the undeveloped mountain areas, with the preserved natural resources and life environment.

Bearing in mind the ecological quality, and above all the preservation of the natural resources in Serbia, it is possible to provide better: a market position, strong competitiveness, long-term development sustainability and ultimately higher profitability. On the other hand, starting from the needs of tourists (having in mind the marketing concept as the basic business function of all economic entities), there is a need to harmonize the desire to meet the tourist needs and preserve the environment (Vuković, Cecić, Cvijanović, 2007).

\section{Conflict of interests}

The authors declare no conflict of interest.

\section{References}

1. Bošković, T. (2008): Sustainable tourism as a modern concept of tourism development, Business School, 4, 123-127. [in Serbian: Бошковић, Т. (2008): Одрживи туризам као савремени концепт развоја туризма].

2. Brankov, J. (2010): Ecological tourism in protected areas in Banat, Geographical Institute “Jovan Cvijic” SANU, Belgrade . [in Serbian: Бранков, J. (2010): Еколошки туризам у заштићеним објектима природе у Банату].

3. Brankov, J. (2015): Sustainable tourism in national parks in Serbia (Unpublished doctoral dissertation). Faculty of Geography, University of Belgrade, Belgrade. 
4. Brankov, J., Jovičić, D., \& Milijašević, D. (2015): Sustainable Tourism in National Park "Đerdap", Serbia - Attitudes of Local Population, Journal of the Geographical Institute “Jovan Cvijič” SASA, 65(2), 183-199.

5. Briassoulis, H., \& Van der Straaten, J. (Eds.) (2013): Tourism and the Environment: Regional, Economic, Cultural and Policy Issues (2nd Ed.), Dordrecht: Springer-Science and Business Media.

6. Drumm, A., Moore, A., Soles, A., Patterson, C., \& Terborgh, J. (2004): Ecotourism Development-A Manualfor Conservation Planners and Managers, The Business of Ecotourism Development and Management, Arlington, USA, The Nature Conservancy.

7. Eagles, P.F.J., \& McCool, S.F. (2002): Tourism in National Parks and Protected Areas: Planning and Management, Wallingford: CABI Publishing.

8. Holden, A. (2016): Environment and Tourism (3rd Ed.), London and New York: Routledge, Taylor \& Francis Group.

9. Hrabovski Tomić, E., \& Milićević, S. (2012): Sustainable development principles in the development of the Vrnjačka banja tourism, Teme, 36(2), 755-771. [in Serbian: Храбовски Томић, Е., Милићевић, С. (2012): Развој туризма Врњачке Бање на принципима одрживог развоја].

10. Jovičić, D., \& Ilić, T. (2010). Sustainable Tourism Indicators, Glasnik srpskog geografskog društva, 90(1). [in Serbian: Јовичић, Д., \& Илић, Т. (2010): Индикатори одрживог туризма].

11. Krunić, N., Milijić, S., \& Đurđević, J. (2010). Development of mountain tourism in Serbia and surrounding countries, Architecture and Urbanism, 29, 3-9. [in Serbian: Крунић, Н., Милијић, С., \& Ђурђевић, Ј. (2010): Развој планинског туризма у Србији и земЉама у окружењу].

12. Maksin, M., Pucar, M., Korać, M., \& Milijić, S. (2009): Management of Natural and Cultural Resources in Tourism, Singidunum University, Belgrade. [in Serbian: Максин, М., Пуцар, М., Кораћ, М., \& Милијић, С. (2009): Менаџмент природних и културних ресурса у туризму]

13. Miller, G. (2001). The development of indicators for sustainable tourism: results of a Delphi survey of tourism researchers. Tourism management, 22(4), 351-362.

14. Neto, F. (2003). A new approach to sustainable tourism development: Moving beyond environmental protection. In Natural resources forum, 27(3), 212-222.

15. Nyaupane, G. P., \& Poudel, S. (2011): Linkages among biodiversity, livelihood, and tourism, Annals of Tourism Research, 38(4), 1344-1366.

16. Popesku, J. (2016): Management of tourist destination, Singidunum University, Belgrade. [in Serbian: Попеску, J. (2016): Менаџмент туристичке дестинације]. 
17. Statistical Office of the Republic of Serbia - SORS (2011, 2012, 2016): Statistical Yearbook of the Republic of Serbia, Belgrade. [Republički zavod za statistiku - RZZS Statistički godišnjak Republike Srbije].

18. Sharpley, R. (2009): Tourism Development and the Environment: Beyond Sustainability?, London: Earthscan.

19. Štetić, S., Cvijanović, D., \& Šimičević, D. (2014): Special forms of tourism of the Danube region of Serbia, Institute of Agricultural Economics, Belgrade. [in Serbian: Штетић, С., Цвијановић, Д., \& Шимичевић, Д. (2014): Посебни облици туризма дунавског региона Србије].

20. Stojanović, V. (2011): Tourism and Sustainable Development, Novi Sad: Faculty of Science. [in Serbian: Стојановић, B. (2011): Туризам и одрживи развој].

21. Vuković, P., Cecić, N., \& Cvijanović, D. (2007). Sustainable tourist development of rural areas in Serbia, Ekonomika poljoprivrede, 54(3), 369-379.

22. Weaver, D. (2006): Sustainable Tourism: Theory and Practice, Ohford: Elsevier Butterworth-Heinemann.

23. Williams, P. I., \& Ponsford, I. F. (2009): Confronting tourism's environmental paradox: Transitioning for sustainable tourism, Futures, 41, 396-404.

24. World Tourism Organization (2004). Indicators of sustainable development for tourism destinations: a guidebook. WTO. 